\title{
Physicochemical and Antimicrobial Properties of Biopolymer-Candelilla Wax Emulsion Films Containing Potassium Sorbate - A Comparative Study
}

\author{
Dariusz Kowalczyk • Monika Kordowska-Wiater • \\ Bartosz Solowiej • Barbara Baraniak
}

Received: 30 May 2014 / Accepted: 6 October 2014 / Published online: 21 October 2014

(C) The Author(s) 2014. This article is published with open access at Springerlink.com

\begin{abstract}
The comparative studies were performed in order to assess the most suitable matrix polymer for potassium sorbate (KS). The preservative $(1.0,2.0,3.0,4.0 \% \mathrm{w} / w)$ was included into edible films made from different biopolymers: carboxymethyl cellulose (CMC), oxidized potato starch (OPS), soy protein isolate (SPI), gelatin (GEL), sorbitol, candelilla wax, and emulsifier. The incorporation of KS dramatically reduced the toughness of all tested films. The plasticizing action of KS was the weakest in CMC-based films, which exhibited the highest initial stiffness and the lowest stretchability. With the exception of GEL films, KS addition caused an increase in water vapor permeability of the films. Moreover, except for CMC films, increased KS content in the films led to increase in the stickiness, moisture content, and solubility. CMC-based films, regardless of the concentration of KS, had unchanged hygroscopicity and were completely water-soluble. In most cases, KS reduced transmission of light through the films. OPS, SPI, and GEL films, in contrast to CMC-based ones, exhibited sorbitol crystallization; however, the addition of KS successfully overcame this disadvantage. The antimicrobial effectiveness of all tested films increased by increasing the KS concentration. The kind of carrier used affected antimicrobial effectiveness of KS, and SPI films tended to have the weakest antibacterial and antifungal
\end{abstract}

D. Kowalczyk $(\bowtie) \cdot$ B. Baraniak

Department of Biochemistry and Food Chemistry, University of Life Sciences in Lublin, Skromna 8, 20-704 Lublin, Poland

e-mail: dariusz.kowalczyk@up.lublin.pl

M. Kordowska-Wiater

Department of Biotechnology, Human Nutrition and Science of Food Commodities, University of Life Sciences in Lublin, Skromna 8, 20-704 Lublin, Poland

B. Sołowiej

Department of Milk and Hydrocolloids Technology, University of Life Sciences in Lublin, Skromna 8, 20-704 Lublin, Poland activity, especially at low KS content. The data given here may provide a useful guide in establishing the best compromise between conflicting film property demands. Taken together, our findings suggest that the CMC films could be the best carrier for KS.

Keywords Edible films $\cdot \mathrm{CMC} \cdot$ Oxidized potato starch . SPI · Gelatin · Potassium sorbate

\section{Introduction}

Research and technological development in the field of active packaging materials is very dynamic and evolves in step with the search for environmentally friendly packaging solutions. In this context, the design of tailor-made packaging is a real challenge, and it implies the use of reverse engineering approaches based on food requirements and not just on the availability of packaging materials any longer. Packaging materials with active components provide additional functionality such as scavenging of gases $\left(\mathrm{O}_{2}, \mathrm{CO}_{2}\right.$, ethylene), regulation of humidity content, and antioxidant or antimicrobial activity. The emission of preservatives can extend the shelf life of food and help control the growth of pathogenic (or harmful) microorganisms in potentially hazardous products. Probably for this reason, antimicrobial packaging is one of the most promising and rapidly emerging technologies. Sorbic acid (2,4-hexadienoic acid) and its salts have several advantages as food preservatives. They are highly active against molds, yeasts, and bacteria; their effective concentrations normally do not alert the taste or odor of a food product, and they are considered generally recognized as safe (GRAS). Potassium sorbate (KS) is more commonly used because of its stable nature and higher solubility $\left(58.2 \%, 20{ }^{\circ} \mathrm{C}\right)$ compared to sorbic acid $\left(32.0 \%, 20^{\circ} \mathrm{C}\right)$. The inhibitory effect of KS may by lethal as well as static, depending on the concentration and 
the $\mathrm{pH}$ of the medium. Low concentrations of KS ( 0.05 to $0.3 \%$ by weight) are sufficient to reduce microbial growth in food, but the use of KS is effective up to $\mathrm{pH}$ 6.5. Consequently, the $\mathrm{pH}$ of the packaging material and the food to which packaging is applied are important parameters (Pérez et al. 2014; Theron and Rykers 2011). Numerous trials have been aimed at the invention of an appropriate technology for KS-containing antimicrobial polymer materials. A great deal of research has been dedicated to developing active packages through the use of edible films and coatings (Basch et al. 2013; Famá et al. 2005; Flores et al. 2007; Garcia et al. 2012; Kristo et al. 2008; Mehyar et al. 2014; Ofman et al. 2004; Ozdemir and Floros 2001, 2003; Pérez et al. 2014; Sayanjali et al. 2011; Shen et al. 2010; Valencia-Chamorro et al. 2008). The application of these kinds of materials is one of the innovations of packaging technology aiming to improve the mechanical properties of the food, minimize respiration in fruits and vegetables, limit the movement of moisture and other gases, provide antimicrobial or antioxidant capabilities to the product, enhance the sensory properties, and extend the shelf life of the product. Edible polymeric packaging may be produced with the use of various components such as polysaccharides, proteins, lipids, plasticizers, and emulsifiers. The multicomponent composition gives a possibility of obtaining of the desired functional characteristics of material. Polysaccharides or proteins provide good mechanical strength, adhesion to the food surface, and enhance barrier properties to oxygen and carbon dioxide. The addition of plasticizers, predominantly polyols, increases the material's elasticity and makes it less brittle. In turn, lipids reduce water vapor permeability (WVP). Among the range of different hydrophobic substances, candelilla wax represent the best barrier to moisture (Krochta 2002), thus it has potentially the best ability to improve barrier properties.

Several studies have shown that by changing the matrix composition, the active film can be alerted to release the antimicrobial at a desired rate (Franssen et al. 2004; Ozdemir and Floros 2003). For the control of microorganism growth, the concentration of antimicrobial on the food surface should be maintained above the minimal inhibitory concentration (MIC). Antimicrobials can interact with the film components and as a consequence, some properties of either the preservative (e.g., solubility, diffusivity, partition coefficient) and the carrier can be modified, affecting the technological features. The nature of these interactions depends on the type of biopolymer as well as on the concentration of the preservative (Kurup et al. 1995; Mansour and Guth 1968; Ofman et al. 2004). So far, a number of studies have investigated the effect of KS on the physical and antimicrobial properties of various biopolimeric films. However, to the best of our knowledge, there have been no previous comparative studies performed in order to assess the most suitable matrix polymer for KS. Materials selection and design for structural biopolymers is becoming increasingly important for different industrial products. The principles for polymer selection for antimicrobial packaging must consider different aspects of the raw material, such as price and accessibility, health safety, susceptibility to microbial degradation, functional properties (e.g., barrier, mechanical, and optical properties), and the possibility of interactions with food components or with active additives, etc.

In this study, we tested four kinds of the commonly used film-forming agents, such as carboxymethyl cellulose (CMC), oxidized potato starch (OPS), soy protein isolate (SPI), and gelatin (GEL), that comprised a wide range of functional properties. Cellulose, the most abundant organic polymer on earth, and its derivatives are an important source of biopolymers for food packaging. Modified forms of cellulose are more resistant to microbial attack and enzymatic cleavage than native cellulose (Allsopp et al. 2004), which renders them the preferred material in antimicrobial packaging. Carboxymethyl cellulose (CMC) is used as a thickener, water retention agent, and structural or adhesive component in various applications, including commercial fruit coating formulation called Semperfresh ${ }^{\mathrm{TM}}$. The films based on CMC are strong, stiff, transparent, and easily water-soluble (Kowalczyk and Baraniak 2014). Sayanjali et al. (2011) demonstrated that incorporation of $\mathrm{KS}$ into $\mathrm{CMC}$ films provides the desired antimicrobial effect but led to weakening of the polymer structure.

Starch is a ubiquitous naturally occurring carbohydrate that is stored in granular form in many plants as an energy reserve. Because of abundance, low-cost, and ability to be processed on conventional plastic processing equipment, starch is one of the most promising biodegradable polymers for use as component in packaging materials. In order to increase the industrial applications, the starches are modified by the physical, chemical, or enzymatic treatments. The oxidation results in partially converted or degraded starches that have unique functional properties such as low viscosity, high stability, clarity, reduced microbiological content, and excellent filmforming properties (Kuakpetoon and Wang 2001). Ofman et al. (2004) showed that KS had great influence on sorption and mechanical properties of starch systems, affecting film functionality. Also, a starch-preservative interaction was proven to occur, and recognized as a factor that might affect antimicrobial efficiency of the systems (Ofman et al. 2004; Shen et al. 2010).

Soy protein is an abundant and relatively cheap ingredient source for various food applications, including films formation. However, food processors considering use of soy protein-based films must be aware that soya bean (as well as cereals containing gluten, eggs, fish, peanuts, milk, lupine, and products thereof) is on the list of products that are the common cause of allergies and feeding intolerance (Commission Directive 2007/68/EC). In general, soy proteins 
have very good barrier properties to oxygen, but not to water vapor (Krochta 2002). The poor moisture resistance, however, can be circumvented by mixing them with natural lipids (Kowalczyk and Baraniak 2014). Among all proteins, gelatin (GEL) has attracted the attention for the development of biodegradable films. GEL is a protein resulting from partial hydrolysis of collagen-one of the strongest and the most prevalent protein in the animal kingdom. The film-forming ability of collagen has been traditionally used for production of sausage casings. In turn, the film-forming properties of GEL were appreciated in the pharmaceutical and food industry for production of capsules.

The aim of the current study was to assess the potential of different biopolimeric emulsion-based edible films containing varying concentrations of $\mathrm{KS}$ in view of their industrial applications. Water affinities (moisture content, solubility, water vapor permeability), mechanical, and optical properties of films were investigated and compared. Also, the effects of the carrier type and KS concentration on the antimicrobial activity were tested against bacteria and phytopathogenic fungi. The data given here may provide a useful guide in establishing the best compromise between conflicting film property demands.

\section{Materials and Methods}

\section{Materials}

Commercial food-grade biopolymers were used in this study: sodium carboxymethyl cellulose 30 GA (Dow-Wolff Cellulosics, Germany); oxidized potato starch LU-1404-2 (WPPZ S.A. Luboń, Poland); soy protein isolate GS5200A (Gushen Biological Technology Group Co., LTD, China); and pork gelatin (McCormick-Kamis Polska S.A, Poland). Candelilla wax SP-75 was purchased from Strahl \& Pitsch Inc (USA). Sorbitol (Sor), potassium sorbate (KS), and Tween 40 were purchased from Sigma Chemical Co., St. Louis, MO (USA).

\section{Film Preparation}

Films were obtained from $5 \%(w / w)$ aqueous biopolymer solutions containing $3 \%(w / w)$ Sor, $0.5 \%(w / w)$ candelilla wax, and $0.35 \%(w / w)$ Tween 40 . Polymer powders were mixed with Sor and water, then heated in a water bath at $90{ }^{\circ} \mathrm{C}$ for $30 \mathrm{~min}$ with constant stirring. In the case of OPS, the heating time was prolonged to $1 \mathrm{~h}$ in order to reduce viscosity. Before the end of heating, a melted mixture of candelilla wax and surfactant was added, and the solution was emulsified with a homogenizer (H-500, Pol-Eko Aparatura, Poland) at $27,000 \mathrm{rpm}$ for $2 \mathrm{~min}$, then, at 20,000 rpm for $3 \mathrm{~min}$. The filmforming solutions (FFSs) were cooled to $50{ }^{\circ} \mathrm{C}$, and $\mathrm{KS}$ was introduced in concentrations 1.0, 2.0, 3.0, and 4.0\% $(w / w)$. Formulations without KS served as the controls. The $\mathrm{pH}$ of FFSs was determined by using a $\mathrm{pH}$ meter. The emulsions were cast onto leveled polycarbonate trays $(12 \times 12 \mathrm{~cm})$ and dried at $25 \pm 1{ }^{\circ} \mathrm{C}$ for $\sim 24 \mathrm{~h}$. A constant amount of the $0.011 \mathrm{~g}$ of total solids was cast onto $1 \mathrm{~cm}^{2}$ of tray area, in order to maintain film thickness. The films were peeled from the trays and cut prior to testing.

\section{Film Thickness and Conditioning}

Thickness of the films was determined using a manual micrometer (Mitotuyo No. 7327, Tokyo, Japan). Before testing, film specimens were conditioned for $48 \mathrm{~h}$ in a test chamber (MLR-350, Sanyo Electric Biomedical Co. Ltd., Japan) at $50 \%$ relative humidity $(\mathrm{RH})$ and $25^{\circ} \mathrm{C}$.

\section{Moisture Content and Total Soluble Matter}

Film specimens $(2 \times 2 \mathrm{~cm})$ were weighed $( \pm 0.0001 \mathrm{~g})$ and dried in an oven at $105{ }^{\circ} \mathrm{C}$ for $24 \mathrm{~h}$ to a constant weight. The weight loss of each sample was determined, and the moisture content (MC) was calculated as the percentage of water removed from the system. The total soluble matter (TSM) was expressed as the percentage of film dry matter solubilized after $24 \mathrm{~h}$ immersion in water. Each dried sample was shaken in $30 \mathrm{ml}$ of distilled water at $25 \pm 1{ }^{\circ} \mathrm{C}$ for $24 \mathrm{~h}$. Film samples were then removed from the solution and redried at $105^{\circ} \mathrm{C}$ for $24 \mathrm{~h}$ to determine solubilized dry matter. Initial dry matter values needed for TSM calculations were obtained from MC measurements for the same film. Analyses were performed in quadruplicate.

\section{Water Vapor Permeability}

The water vapor permeability (WVP) $\left(\mathrm{g} \mathrm{mm} \mathrm{m}^{-2} \mathrm{~d}^{-1} \mathrm{kPa}^{-1}\right)$ was calculated as follow:

$\mathrm{WVP}=(\mathrm{WVTR} \times L) / \Delta p$

where WVTR is the water vapor transmission rate of film $\left(\mathrm{g} \mathrm{m}^{-2} \mathrm{~d}^{-1}\right), L$ is the mean of film thickness $(\mathrm{mm})$, and $\Delta \mathrm{p}$ is the water vapor pressure difference $(\mathrm{kPa})$ between two sides of the film.

The WVTR of the films was measured gravimetrically based on the PN-ISO 2528 (2000) method. The permeation cell (poly(methyl methacrylate) cups had an internal diameter of $7.98 \mathrm{~cm}$ (exposed film area $=50 \mathrm{~cm}^{2}$ ) and an internal depth of $2 \mathrm{~cm}$. Distilled water $(30 \mathrm{~mL})$ was added into each test cup and film samples were placed over the circular opening and secured by a screw top. The upper side of the films, exposed to air during casting, was exposed to the water. The cups were placed in an environmental chamber set at $25{ }^{\circ} \mathrm{C}$ and $50 \%$ 
RH. The weight loss from the samples with three replicates was monitored for $10-12 \mathrm{~h}$ periods with weights recorded at $2 \mathrm{~h}$ intervals.

\section{Light Transmission and Film Opacity}

The light barrier properties of the films were measured at selected wavelengths between 200 and $800 \mathrm{~nm}$ using a spectrophotometer (Lambda 40, Perkin-Elmer, Shelton, CT, USA). The opacity (Op) of the films was calculated by Eq. (2) (Han and Floros 1997):

$\mathrm{Op}=\mathrm{A}_{600} / x$ or $-\log \mathrm{T}_{600} / x$

where $\mathrm{A}_{600}$ is the absorbance at $600 \mathrm{~nm}, \mathrm{~T}_{600}$ is the transmittance at $600 \mathrm{~nm}$, and $x$ is the film thickness (mm). Analyses were performed in quadruplicate.

\section{Mechanical Properties}

The mechanical properties of films were evaluated using a TA-XT2i texture analyzer (Stable Micro Systems, UK). The initial grip separation was set to $30 \mathrm{~mm}$, and film samples $(2 \times$ $5 \mathrm{~cm}$ ) were stretched at speed of $1 \mathrm{~mm} \mathrm{~s}^{-1}$. At least eight replicates of each film type were tested for tensile properties. Tensile strength (TS, MPa), elongation at break (E, \%), and elastic modulus (EM, MPa) were calculated by Eqs. (3), (4), and (5), respectively:

$\mathrm{TS}=F_{\mathrm{t}} / A_{\mathrm{t}}$

where $F_{\mathrm{t}}$ is the maximum load for breaking film (N) and $A_{\mathrm{t}}$ is the initial specimen cross-sectional area (thickness $\times$ width, $\mathrm{mm}^{2}$ ).

$E=(\Delta L / L) \times 100$

where $L$ is the initial gage length $(\mathrm{mm})$ and $\Delta L$ is the difference in the length at the moment of fracture.

$\mathrm{EM}=\left(\sigma_{2}-\sigma_{1}\right) /\left(\varepsilon_{2}-\varepsilon_{1}\right)$

where $\varepsilon_{1}$ is a strain of $0.005(0.5 \%), \varepsilon_{2}$ is a strain of 0.0133 $(1.33 \%), \sigma_{1}(\mathrm{MPa})$ is the stress at $\varepsilon_{1}$, and $\sigma_{2}(\mathrm{MPa})$ is the stress at $\varepsilon_{2}$.

Puncture strength (PS, MPa) was determined by the method of Ghorpade et al. (1995), with some modifications. A steel ball-ended probe ( $2 \mathrm{~mm}$ diameter) was moved perpendicularly at the film surface at constant speed $\left(1 \mathrm{~mm} \mathrm{~s}^{-1}\right)$ until it passed through the film. The PS was calculated by Eq. (6):

$\mathrm{PS}=F_{\mathrm{p}} / A_{\mathrm{p}}$

were $F_{\mathrm{p}}$ is the maximum force $(\mathrm{N})$ and $A_{\mathrm{p}}$ is the crosssectional area of the probe (thickness $\times$ diameter of the opening of film holder, $\mathrm{mm}^{2}$ ). PS was measured in quadruplicate.
Plasticizer Crystallization

Film samples $(12 \times 12 \mathrm{~cm})$ were stored in the test chamber $\left(50 \% \mathrm{RH}, 25{ }^{\circ} \mathrm{C}\right)$ for 3 months. The percentage area of sorbitol crystals (white spots) appearing on the film surface was estimated using a histogram tool of image editing software, via counting the number of white pixels exposed in black-and-white photos of the films (Kowalczyk and Baraniak 2014).

Minimal Inhibitory Concentration and Minimal Bactericidal/Fungicidal Concentration

Pathogenic and spoilage bacteria: Escherichia coli, Staphylococcus aureus, Bacillus cereus, Pectobacterium carotovorum, and phytopathogenic fungi: Botrytis cinerea Pers. ex Nocca \& Balb, Monilinia fructigena (Aderhold et Ruhland) Honey, Alternaria alternata (Fr.) Keissler, and Rhizopus nigricans were used for testing. Bacteria and fungi were maintained at $4{ }^{\circ} \mathrm{C}$ on nutrient agar (BTL, Poland) and potato dextrose agar (BTL, Poland) slants, respectively.

The minimal inhibitory concentration (MIC) of KS was determined by the tube dilution method. Initial bacteria inocula corresponding to $0.5 \mathrm{McF}$ arland standard were prepared in sterile saline. Aqueous solutions of KS in concentrations 1$200 \mathrm{mg} / \mathrm{ml}$ were mixed with nutrient broth (for bacteria) or malt broth (for fungi), then $0.05 \mathrm{ml}$ of inocula were added into each tube. The final concentrations of KS ranged from 0.1 to $20 \mathrm{mg} / \mathrm{ml}$. Test tubes were incubated at $37{ }^{\circ} \mathrm{C}$ (for E. coli, S. aureus, B. cereus) and $30^{\circ} \mathrm{C}$ (for P. carotovorum) for 24 $48 \mathrm{~h}$. The MIC, defined as the lowest concentration of antimicrobial that inhibited the visible growth of a microorganism after incubation, was determined turbidimetrically. Each test included a control-the medium without $\mathrm{KS}$ in which a good growth of bacteria was observed. MIC for fungi was determined similarly, but spore suspensions were used as initial inocula. Tubes were incubated at $28{ }^{\circ} \mathrm{C}$ for $2-7$ days and everyday were visually analyzed for the growth of mycelia. Additionally, all microorganisms were transferred on agar plates in order to check the minimal bactericidal/fungicidal concentration (MBC/MFC), defined as the lowest concentration of antimicrobial that prevent the growth of an organism after subculture on to antimicrobial-free media. Measurements were performed in triplicate.

Antimicrobial Activity of Films

Antibacterial and antifungal activities of the films were assayed by the disc diffusion method. Film discs with a diameter of $11 \mathrm{~mm}$ were prepared as previously described, but in sterile conditions. The discs were placed on the surface of nutrient agar plates, which has been previously seeded with each bacterial suspension $(0.2 \mathrm{ml})$ adjusted to $1 \mathrm{McF}$ arland 
standard (approximately $10^{6} \mathrm{cfu} \mathrm{ml}^{-1}$ ) in saline solution. The upper side of the films (exposed to air during casting) was exposed to the air. Next, the plates were incubated at $37{ }^{\circ} \mathrm{C}$ (E. coli, S. aureus, and B. cereus) and $30^{\circ} \mathrm{C}$ (P. carotovorum) for $48 \mathrm{~h}$. After incubation, the diameter of the inhibition zone represented by a clear area of non-growth or a decreased growth around the film disc was measured perpendicularly to the nearest millimeter with a caliper, and then reduced by the film discs' diameter. This difference was reported as the inhibition zone diameter of the films.

To evaluate the antifungal effect, the film discs were applied on the surface of potato dextrose agar plates, which has been previously seeded with $0.2 \mathrm{ml}$ of fungal spore suspensions $\left(10^{6}\right.$ spores $\left.\mathrm{ml}^{-1}\right)$. Plates were incubated at $28^{\circ} \mathrm{C}$ for 2 days ( $R$. nigricans, A. alternata) and 6 days (B. cinerea, Monilinia fructigena). Antimicrobial activity measurements were performed in triplicate.

\section{Statistical Analysis}

All data were expressed as mean \pm standard deviation $(n \geq 3)$. Differences among data mean values were tested for statistical significance at the $p<0.05$ level using a two-way analysis of variance (STATISTICA 6.0, StatSoft Inc., Tulsa, USA) and the Fisher's test.

\section{Results and Discussion}

Coherent emulsion films were prepared when KS was added at concentrations between 1 and $4 \%(w / w)$ (corresponding to 0.2-0.8 g KS per $1 \mathrm{~g}$ of film-forming agent). As the KS incorporation level increased, the OPS, SPI, and GEL films became more sticky. The adhesion-growth effect was not observed for CMC films. The preliminary tests showed that above $4.0 \%$ of KS, films become opaque with a whitish bloom at the surface (CMC and SPI films), extremely sticky (OPS, SPI, GEL films), and weak, making them unsuitable to use. The high adherence and stretchability of GEL films cast from FFS containing $4 \% \mathrm{KS}$ made it impossible to peel them off from the casting surface. Consequently, in this work the properties of GEL film at $4 \%$ of KS were not studied.

\section{MC and TSM}

Incorporation of KS significantly increased the MC of OPS, SPI, and GEL films (Table 1). This was due to the strong hygroscopic character of KS (Famá et al. 2005; Kristo et al. 2008). The moisture-growth effect, however, was not observed for CMC films $(p>0.05)$. A possible explanation for this result may be that at the applied test conditions $(\mathrm{RH}=$ $50 \%) \mathrm{CMC}$ and $\mathrm{KS}$ had similar moisture sorption ability. The numerous hydrophilic groups (hydroxyl and carboxylic) in the $\mathrm{CMC}$ structure give it an excellent water binding ability. It is also possible that the electrostatic repulsion between the negatively charged sorbate and the anionic $\mathrm{CMC}$ molecules was so strong that fewer electrostatic interactions between water and $\mathrm{KS}$ or water and $\mathrm{CMC}$ were possible. According to Flores et al. (2007), incorporation of sorbates may interfere with the biopolymers through the development of hydrogen bonds between polymer chains and the antimicrobial agent, which would replace the chain-chain interactions and would inhibit the formation of water-polymer hydrogen bonds in the film water sorbent interface.

SPI films, regardless of the KS incorporation level, tended to have the highest MC. This result could be attributed to the changes in conformation and initial swelling of the protein matrix. Soy proteins have many polar hydrophilic groups, such as imino, amino, carboxyl, hydroxyl, carbonyl, and sulfhydryl groups, that could easily interact with water to result in swelling. KS, as a hygroscopic substance, facilitates the water penetration into the polymeric matrix, causing intensive hydration of proteins (Ozdemir and Floros 2001). Furthermore, it is also possible that polymer-KS associations resulted in loosening the compactness of the polymer structure (Pranoto et al. 2005), thus more water was immobilized into crevices of soy protein matrix.

Solubility is a critical parameter determining the usefulness of biopolymer packaging in many technological applications. The use of edible films on high- $\mathrm{a}_{\mathrm{w}}$ food requires these materials to be water resistant. On the other hand, water-soluble packaging could provide a convenient delivery system for a wide range of products including agricultural products, concrete additives, pigments, industrial batch chemicals, etc. It can be seen from the data in Table 1 that the CMC-based films were completely water-soluble, while the other films were only partially soluble. The possible reasons for these differences have been described previously (Kowalczyk and Baraniak 2014). With the exception of CMC films, KSincorporated films had significantly higher TSM as compared to control films. The film solubility gradually increased as the KS concentration increased. This finding can be easily explained in terms of the film composition changes. Because the total solid levels in the cast FFSs remained constant, the incorporation of a low molecular hydrophilic preservative increased the soluble matter present in the films, giving structures more sensitive to water. A similar effect is often observed with increasing concentrations of hydrophilic plasticizers (Bergo et al. 2013; Farahnaky et al. 2013). Enhanced solubility of the films might also be because of KS-polymer associations, weakening chain packaging in the polymeric network, which facilitated water penetration into the film matrix (Basch et al. 2013; Flores et al. 2007). Among the studied films, the highest growth in TSM after KS incorporation was observed for OPS films. This result may be explained by the fact that 
Table 1 Effect of potassium sorbate concentration on the $\mathrm{pH}$ of film-forming solutions (FFSs) and the moisture content (MC), total soluble matter (TSM), water vapor permeability (WVP), and opacity (Op) of biopolimer-candelilla wax emulsion films

\begin{tabular}{|c|c|c|c|c|c|c|}
\hline Films & KS (\%) & $\mathrm{pH}$ of FFS & $\mathrm{MC}(\%)$ & TSM $(\%)$ & WVP $\left(\mathrm{g} \mathrm{mm} \mathrm{m}^{-2} \mathrm{~d}^{-1} \mathrm{kPa}^{-1}\right)$ & $\mathrm{Op}\left(\mathrm{A}_{600} / \mathrm{mm}\right)$ \\
\hline \multirow[t]{5}{*}{$\mathrm{CMC}$} & 0 & $6.32 \pm 0.04^{\mathrm{d}}$ & $10.65 \pm 0.48^{\mathrm{bcd}}$ & $100.00 \pm 0.00^{\mathrm{k}}$ & $29.52 \pm 1.49^{\mathrm{c}}$ & $6.34 \pm 0.28^{\mathrm{g}}$ \\
\hline & 1.0 & $6.70 \pm 0.00^{\mathrm{f}}$ & $10.29 \pm 1.07^{\mathrm{bc}}$ & $100.00 \pm 0.00^{\mathrm{k}}$ & $37.75 \pm 0.74^{\mathrm{efg}}$ & $7.68 \pm 0.42^{\mathrm{h}}$ \\
\hline & 2.0 & $6.89 \pm 0.01^{\mathrm{hi}}$ & $10.50 \pm 1.31^{\mathrm{bcd}}$ & $100.00 \pm 0.00^{\mathrm{k}}$ & $39.26 \pm 0.5^{\mathrm{gh}}$ & $9.76 \pm 0.67^{\mathrm{j}}$ \\
\hline & 3.0 & $7.09 \pm 0.04^{\mathrm{kl}}$ & $10.53 \pm 0.75^{\mathrm{bcd}}$ & $100.00 \pm 0.00^{\mathrm{k}}$ & $41.42 \pm 0.38^{\mathrm{hi}}$ & $8.68 \pm 0.51^{\mathrm{i}}$ \\
\hline & 4.0 & $7.17 \pm 0.01^{\mathrm{lm}}$ & $10.30 \pm 0.71^{\mathrm{bc}}$ & $100.00 \pm 0.00^{\mathrm{k}}$ & $44.49 \pm 2.27^{\mathrm{j}}$ & $9.11 \pm 0.11^{\mathrm{ij}}$ \\
\hline \multirow[t]{5}{*}{ OPS } & 0 & $4.84 \pm 0.14^{\mathrm{a}}$ & $7.03 \pm 0.27^{\mathrm{a}}$ & $36.34 \pm 1.59^{\mathrm{a}}$ & $26.82 \pm 1.74^{\mathrm{b}}$ & $1.65 \pm 0.11^{\mathrm{ab}}$ \\
\hline & 1.0 & $6.52 \pm 0.03^{\mathrm{e}}$ & $10.50 \pm 1.09^{\mathrm{bcd}}$ & $62.10 \pm 2.87^{\mathrm{g}}$ & $31.35 \pm 1.50^{\mathrm{c}}$ & $2.31 \pm 0.05^{\mathrm{b}}$ \\
\hline & 2.0 & $6.83 \pm 0.03^{\mathrm{gh}}$ & $10.99 \pm 1.15^{\mathrm{cd}}$ & $71.29 \pm 2.19^{\mathrm{i}}$ & $35.16 \pm 1.23^{\mathrm{d}}$ & $3.04 \pm 0.16^{\mathrm{c}}$ \\
\hline & 3.0 & $7.02 \pm 0.02^{\mathrm{jk}}$ & $11.42 \pm 0.88^{\mathrm{de}}$ & $72.19 \pm 0.79^{\mathrm{i}}$ & $37.92 \pm 0.08^{\mathrm{efg}}$ & $3.01 \pm 0.19^{\mathrm{c}}$ \\
\hline & 4.0 & $7.19 \pm 0.01^{\mathrm{m}}$ & $11.42 \pm 0.25^{\mathrm{de}}$ & $76.32 \pm 1.23^{\mathrm{j}}$ & $39.84 \pm 0.99^{\mathrm{gh}}$ & $3.58 \pm 0.11^{\mathrm{cd}}$ \\
\hline \multirow[t]{5}{*}{ SPI } & 0 & $6.76 \pm 0.01^{\mathrm{fg}}$ & $7.92 \pm 0.22^{\mathrm{a}}$ & $45.37 \pm 0.38^{\mathrm{b}}$ & $38.96 \pm 1.31^{\mathrm{fgh}}$ & $7.92 \pm 0.17^{\mathrm{h}}$ \\
\hline & 1.0 & $6.83 \pm 0.01^{\mathrm{gh}}$ & $12.09 \pm 0.37^{\mathrm{e}}$ & $49.93 \pm 1.43^{\mathrm{d}}$ & $40.84 \pm 0.3^{\mathrm{h}}$ & $3.78 \pm 0.30^{\mathrm{de}}$ \\
\hline & 2.0 & $6.97 \pm 0.02^{\mathrm{ij}}$ & $14.10 \pm 0.53^{\mathrm{f}}$ & $56.01 \pm 2.55^{\mathrm{e}}$ & $43.79 \pm 1.01^{\mathrm{ij}}$ & $4.45 \pm 0.39^{\mathrm{e}}$ \\
\hline & 3.0 & $7.01 \pm 0.01^{\mathrm{jk}}$ & $15.81 \pm 0.75^{\mathrm{g}}$ & $57.54 \pm 0.35^{\mathrm{ef}}$ & $48.21 \pm 1.72^{\mathrm{k}}$ & $5.50 \pm 0.41^{\mathrm{f}}$ \\
\hline & 4.0 & $7.09 \pm 0.01^{\mathrm{kl}}$ & $17.47 \pm 0.83^{\mathrm{h}}$ & $61.38 \pm 1.02^{\mathrm{g}}$ & $55.25 \pm 1.7^{1}$ & $11.54 \pm 1.64^{\mathrm{k}}$ \\
\hline \multirow[t]{5}{*}{ GEL } & 0 & $5.23 \pm 0.01^{\mathrm{b}}$ & $9.78 \pm 0.18^{\mathrm{b}}$ & $47.65 \pm 0.40^{\mathrm{c}}$ & $36.38 \pm 1.36^{\mathrm{de}}$ & $1.09 \pm 0.11^{\mathrm{a}}$ \\
\hline & 1.0 & $6.18 \pm 0.01^{\mathrm{c}}$ & $11.13 \pm 0.22^{\text {cde }}$ & $48.44 \pm 0.87^{\mathrm{cd}}$ & $21.9 \pm 1.06^{\mathrm{a}}$ & $2.29 \pm 0.08^{\mathrm{b}}$ \\
\hline & 2.0 & $6.50 \pm 0.02^{\mathrm{e}}$ & $12.13 \pm 0.43^{\mathrm{e}}$ & $58.34 \pm 0.73^{\mathrm{f}}$ & $31.32 \pm 2.59^{\mathrm{c}}$ & $3.31 \pm 0.07^{\mathrm{cd}}$ \\
\hline & 3.0 & $6.69 \pm 0.02^{\mathrm{f}}$ & $13.60 \pm 0.45^{\mathrm{f}}$ & $66.77 \pm 2.06^{\mathrm{h}}$ & $36.73 \pm 2.92^{\mathrm{def}}$ & $3.35 \pm 0.32^{\mathrm{cd}}$ \\
\hline & 4.0 & $6.86 \pm 0.04^{\mathrm{h}}$ & n.a. & n.a. & n.a. & n.a. \\
\hline
\end{tabular}

Values with the same superscript letters within a column are not significantly different $(p<0.05)$

n.a. not analyzed (films adhered to the casting surface)

incorporation of sorbates contributes to less retrogradation of starch (Flores et al. 2007), thus predominant amorphous regions in the KS-incorporated starch films could cause it to swell in water easily and then to disintegrate (Shen et al. 2010).

\section{WVP}

Since packaging films should maintain the moisture content at a high level to prevent the food product from drying out, WVP should be as low as possible. The results of this study showed that with the exception of GEL films, the addition of KS significantly increased WVP of the films (Table 1). In general, as the KS concentration increased, the barrier properties of the films gradually decreased, which agrees with the findings of other studies (Kristo et al. 2008; Pranoto et al. 2005; Sayanjali et al. 2011; Shen et al. 2010; Türe et al. 2012). KS could interfere with the formation of a compact polymer network, increasing the free volume and polymer permeability (Pranoto et al. 2005). Furthermore, KS is a hydrophilic substance that is expected to absorb molecules of water. The water vapor transport through films is the sum of three phenomena: adsorption, diffusion, and desorption; thus, if the physical adsorption of water from the environment is high, the moisture flow is high too. This relationship could explain the fact that
KS-incorporated SPI films, which were the most hygroscopic, had the highest WVP (Table 1). However, the opposite behavior was observed in the case of GEL films, i.e., despite the enhanced moisture absorbing capacity, their WVP was reduced (at 1.0 and $2.0 \%$ of KS). There are several possible explanations for this result. Valencia-Chamorro et al. (2008) demonstrated that KS has the ability to induce creaming of lipid phase during film formation. So, it is possible that introduction of KS caused emulsion destabilization, resulting in formation of films with a "bilayer-like" structure and reduced WVP. This effect was observed only for GEL, because in the case of the other FFSs, wax separation is possible without addition of another agent (Kowalczyk and Baraniak 2014). Another possible explanation for the observed phenomenon is that GEL films could just immobilize passing aqueous vapor and for this reason WVP seemed reduced.

\section{Light Transmission and Film Opacity}

When an edible film is intended to be used as a coating on food surfaces, transparency is an important attribute that contributes to consumer acceptability. However, the light that passes through the packaging material, especially UV rays, may catalyze oxidation reactions in photosensitive products and reduce their shelf life. For these reasons, the design of 
packaging material has to be considered to obtain, simultaneously, both translucency and the desired light-blocking properties.

The light transmission (T\%) of the films shown in Fig. 1 covers UV light $(<400 \mathrm{~nm})$, visible light $(400-700 \mathrm{~nm})$, and a small portion of IR $(>700 \mathrm{~nm})$. It can be seen that among control films only those based on OPS and GEL exhibited good light transmission (T\%) properties. SPI films were characterized by the lowest vis-IR transmittance but the best barrier properties to UV light; their T\% at the middle of the ultraviolet spectrum (200-280 nm) did not exceed $0.07 \%$ while for CMC, OPS, and GEL films $\mathrm{T} \%{ }_{\lambda=280}$ values reached $7.78,29,01$, and $11.78 \%$, respectively. The barrier properties of proteins against UV light are associated with the presence of UV-absorbing chromophores, especially two aromatic amino acids-tyrosine and tryptophan (Aitken and Learmonth 2000). Films based on GEL were not as good a UV barrier as SPI films, apparently due to its specific amino acid composition. With the exception of SPI films, introduction of KS into the polymer-wax matrix (regardless of concentration) resulted in decreased light transmission (Fig. 1). It seems that solid state of KS particles caused morphological heterogeneity of emulsion films, and thus visible light scatter through the film, resulting in its opaqueness. However, for SPI-based films, an opposite trend was observed, i.e., addition of KS (at concentrations 1.0-3.0\%) enhanced the transmission of light. A possible explanation for this phenomenon may be that KS improved the homogeneity of candelilla wax in the protein matrix. The ionic strength of the protein environment is one the most important factors affecting protein solubility, conformation, and functional properties, including emulsifying capacity. It is important to note that SPI films were the only one of the control films that exhibited wax bloom visible to the naked eye, which, however, was reduced after addition of KS. In accordance with the present results, previous studies on whey protein films have also demonstrated that the addition of KS (0.5-1.5\%) could enhance film transparency (Pérez et al. 2014). It was an interesting observation that the addition of KS significantly enhanced UV-blocking properties (especially in the middle UV) of all tested films. This result may be explained by the fact that KS present strong UV absorption, which is used for its quantitative determination.

The presence of KS increased the opacity of CMC, OPS, and GEL films. In the case of SPI films (as commented on above), the addition of KS improved their transparency; however, at the $4.0 \%$ of KS concentration the films exhibited higher opacity than films without KS $(p<0.05)$.

\section{Mechanical Properties}

Mechanical features are essential when the polymer films are designated to be used as pouches, wraps, casings, etc. In this respect, adequate strength and flexibility is desired to maintain film integrity throughout the production and handling process. Mechanical strength is also important for materials used as a superficial layer, since the defects of material (pin holes and cracks), caused by its insufficient structural integrity, could easily ruin the barrier effectiveness of coatings (Kowalczyk et al. 2014).

Gelatin and CMC, derivatives of structural polymers, produced films with higher mechanical strength and stiffness compared with plant storage polymers (starch and soy proteins) (Table 2). The possible reasons for this have been previously described (Kowalczyk and Baraniak 2014). The incorporation of KS dramatically reduced the TS, PS, and EM of all tested films. When the concentration of KS was increased, the film strength and stiffness decreased progressively. This trend is consistent with the results of other researches (Basch et al. 2013; Famá et al. 2005; Shen et al. 2010), which attributed the decrease in TS and EM to the structural
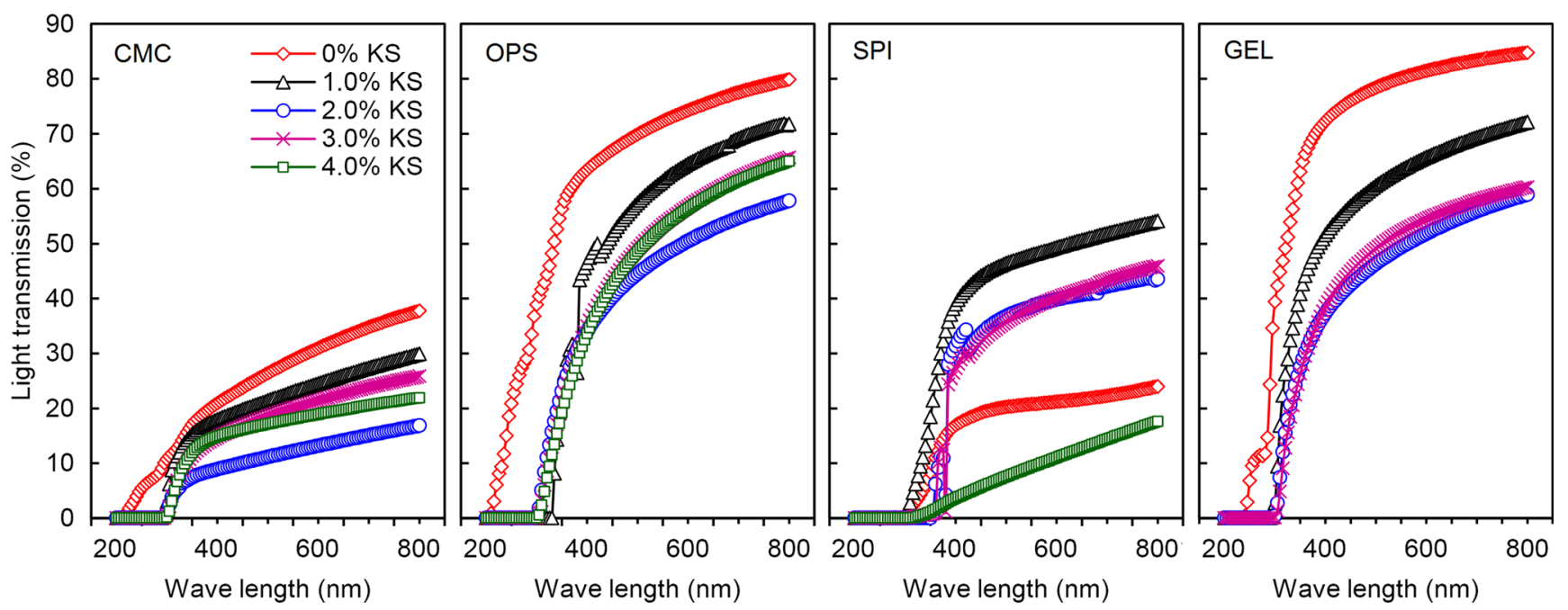

Fig 1 Effect of potassium sorbate concentration on the light transmission of biopolimer-candelilla wax emulsion films 
Table 2 Effect of potassium sorbate concentration on the mechanical properties of biopolimercandelilla wax emulsion films: tensile strength (TS), elongation at break (E), elastic modulus (EM), and puncture strength (PS)

Values with the same superscript letters within a column are not significantly different $(p<0.05)$

n.a. not analyzed (films adhered to the casting surface)

\begin{tabular}{|c|c|c|c|c|c|}
\hline Films & KS (\%) & TS (MPa) & E $(\%)$ & EM (MPa) & PS (MPa) \\
\hline \multirow[t]{5}{*}{$\mathrm{CMC}$} & 0 & $14.62 \pm 0.92^{\mathrm{k}}$ & $21.90 \pm 6.84^{\mathrm{ab}}$ & $217.83 \pm 16.97^{\mathrm{k}}$ & $3.82 \pm 0.09^{1}$ \\
\hline & 1.0 & $10.05 \pm 0.57^{\mathrm{i}}$ & $14.41 \pm 3.81^{\mathrm{a}}$ & $138.67 \pm 9.10 \mathrm{i}$ & $3.30 \pm 0.11^{\mathrm{k}}$ \\
\hline & 2.0 & $8.09 \pm 0.33^{\mathrm{h}}$ & $24.31 \pm 5.88^{\mathrm{ab}}$ & $130.00 \pm 17.72^{\mathrm{i}}$ & $2.16 \pm 0.16^{\mathrm{j}}$ \\
\hline & 3.0 & $6.89 \pm 0.56^{\mathrm{g}}$ & $19.03 \pm 4.36^{\mathrm{a}}$ & $102.01 \pm 13.79^{\mathrm{h}}$ & $1.97 \pm 0.03^{\mathrm{ij}}$ \\
\hline & 4.0 & $6.71 \pm 0.82^{\mathrm{g}}$ & $26.91 \pm 3.21^{\mathrm{ab}}$ & $74.40 \pm 4.66^{\mathrm{g}}$ & $1.79 \pm 0.08^{\mathrm{hi}}$ \\
\hline \multirow[t]{5}{*}{ OPS } & 0 & $3.70 \pm 0.08^{\mathrm{e}}$ & $99.09 \pm 7.87^{\mathrm{fg}}$ & $40.66 \pm 1.87^{\mathrm{f}}$ & $1.63 \pm 0.03^{\mathrm{gh}}$ \\
\hline & 1.0 & $1.56 \pm 0.07^{\mathrm{c}}$ & $140.52 \pm 23.2^{\mathrm{i}}$ & $10.47 \pm 1.27^{\mathrm{d}}$ & $1.0 \pm 0.03^{\mathrm{ef}}$ \\
\hline & 2.0 & $0.96 \pm 0.10^{\mathrm{ab}}$ & $67.18 \pm 6.22^{\mathrm{de}}$ & $8.40 \pm 1.30^{\mathrm{cd}}$ & $0.63 \pm 0.03^{\mathrm{cd}}$ \\
\hline & 3.0 & $0.99 \pm 0.06^{\mathrm{ab}}$ & $81.12 \pm 4.93^{\mathrm{ef}}$ & $5.84 \pm 0.47^{\mathrm{abcd}}$ & $0.50 \pm 0.03^{\mathrm{bc}}$ \\
\hline & 4.0 & $0.67 \pm 0.04^{\mathrm{a}}$ & $48.85 \pm 8.97^{\mathrm{cd}}$ & $4.99 \pm 0.94^{\mathrm{abcd}}$ & $0.30 \pm 0.02^{\mathrm{ab}}$ \\
\hline \multirow[t]{5}{*}{ SPI } & 0 & $4.30 \pm 0.17^{\mathrm{f}}$ & $42.52 \pm 14.88^{\mathrm{bc}}$ & $67.72 \pm 4.55^{\mathrm{g}}$ & $1.59 \pm 0.04^{\mathrm{gh}}$ \\
\hline & 1.0 & $2.29 \pm 0.10^{\mathrm{d}}$ & $127.50 \pm 21.21^{\mathrm{hi}}$ & $25.18 \pm 2.68^{\mathrm{e}}$ & $1.20 \pm 0.09^{\mathrm{f}}$ \\
\hline & 2.0 & $1.28 \pm 0.14^{\mathrm{bc}}$ & $148.87 \pm 13.09^{\mathrm{i}}$ & $7.39 \pm 0.99^{\mathrm{bcd}}$ & $0.84 \pm 0.06^{\mathrm{de}}$ \\
\hline & 3.0 & $1.25 \pm 0.10^{\mathrm{bc}}$ & $183.09 \pm 16.26^{\mathrm{j}}$ & $3.15 \pm 0.77^{\mathrm{abc}}$ & $0.65 \pm 0.03^{\mathrm{cd}}$ \\
\hline & 4.0 & $0.72 \pm 0.05^{\mathrm{a}}$ & $107.73 \pm 7.69^{\mathrm{gh}}$ & $0.75 \pm 0.02^{\mathrm{ab}}$ & $0.34 \pm 0.01^{\mathrm{ab}}$ \\
\hline \multirow[t]{5}{*}{ GEL } & 0 & $24.03 \pm 1.27^{1}$ & $93.48 \pm 14.26^{\mathrm{fg}}$ & $174.52 \pm 15.15^{\mathrm{j}}$ & $11.41 \pm 0.83^{\mathrm{n}}$ \\
\hline & 1.0 & $11.2 \pm 1.43^{\mathrm{j}}$ & $139.64 \pm 15.91^{\mathrm{i}}$ & $46.90 \pm 2.87^{\mathrm{f}}$ & $6.11 \pm 0.10^{\mathrm{m}}$ \\
\hline & 2.0 & $2.43 \pm 0.30^{\mathrm{d}}$ & $313.93 \pm 33.19^{k}$ & $0.67 \pm 0.08^{\mathrm{ab}}$ & $1.44 \pm 0.21^{\mathrm{g}}$ \\
\hline & 3.0 & $1.51 \pm 0.22^{\mathrm{c}}$ & $725.00 \pm 89.25^{1}$ & $0.41 \pm 0.07^{\mathrm{a}}$ & $0.26 \pm 0.04^{\mathrm{a}}$ \\
\hline & 4.0 & n.a. & n.a. & n.a. & n.a. \\
\hline
\end{tabular}

modification of polymer networks, suggesting that KS disrupts the associations of biopolymer chains decreasing the amounts of interchain H-bonds. Taking into account the plasticizer definition, KS can be regarded as a plasticizing agent. Plasticizers work by embedding themselves between the chains of polymers, spacing them apart (increasing the free volume), and thus significantly lowering the glass transition temperature (Tg) for the material and making it softer and more flexible (Wypych 2004). The plasticizing ability of KS was convincingly proved by Türe et al. (2012), who observed that $\mathrm{Tg}$ of wheat gluten films decreased monotonically with increasing KS concentration.

The results of the present study showed that the plasticizing action of KS greatly depended on the type of film-forming agent. KS had the weakest effect on CMC films, causing the lowest reduction in TS, PS, and EM, as well as unchanged values for $\mathrm{E}$ when compared to control films (Table 2). This suggests a minor $\mathrm{KS}$ interference in the linkage of CMC structures. The relatively weak plasticization may also be due to the fact that CMC-based films, regardless of the $\mathrm{KS}$ concentrations, exhibited unchanged (i.e., not increased) MC values (Table 1). It is well known that water is an important plasticizer contributing to the functional characteristics of biopolymeric films. However, our findings showed that the hydration could be less important for some biopolimeric emulsion-based films. For example, it can be seen that at $4.0 \%$ of $\mathrm{KS}$, the MC of SPI film was about 1.5-times higher than that of OPS film (Table 1), while their TS and PS values were the same $(p>0.05)$ (Table 2$)$. KS showed a very potent impact on the mechanical properties of GEL films. At the highest KS incorporation level, the plasticization of GEL was so high that it was not possible to peel off the films. A similar effect is often observed when glycerol is employed above critical concentration levels (Kowalczyk and Baraniak 2011; Yang and Paulson 2000). At the $3.0 \%$ of KS, the E of GEL films was about seven times higher than that of the control film. This extraordinary growth is similar to those reported by Kołodziejska and Piotrowska (2007), who found that the elongation of GEL films containing glycerol in higher concentrations ( $30 \%$ of the substrate mass) was about eight times greater than that of unplasticized samples. Thus, it can be concluded that the plasticizing action of KS is very similar to glycerol.

\section{Plasticizer Crystallization}

It has been demonstrated that use of Sor as a plasticizer may be beneficial, resulting in films with higher mechanical resistance and lower permeability compared to other polyoles (AlHassan and Norziah 2012; Kowalczyk and Baraniak 2011; Kowalczyk et al. 2014). The plasticizing effect of Sor, however, may not be stable during long-term storage. The reason for this is its tendency to recrystallize over time, which could be observed visually from white spots appearing on the film surface (Kowalczyk et al. 2014). This study shows that the possibility of Sor crystallization greatly depends on the type of 
the film-forming agent. As can be seen in Fig. 2, crystallization did not occur in CMC films. The causes behind this may lie in the fact that $\mathrm{CMC}$ acts as a crystallization controller. It reduces or retards growth of sugar crystals in food products, as well as ice-crystals in ice-cream (Glicksman 1963). Control films based on OPS, SPI, and GEL, while initially clear, became covered in white spots. The longer they were stored, the more Sor crystals were observed. The fastest progress of crystallization was in OPS films, which showed the first signs of crystallization within 1 week of their preparation (degree of crystallization $=0.2 \%$ ).

It is well known that proper additives can accelerate or decelerate the crystal growth process. Our study showed that Sor did not crystallize from films incorporated with KS (Fig. 2). This may be attributed to more dissolved state of Sor as a result of increased water content in the KSincorporated films (Table 1).

\section{$\mathrm{MIC}$ and $\mathrm{MBC} / \mathrm{MFC}$}

Results of MICs and MBCs/MFCs obtained for the studied microorganisms are presented in Table 3. The MICs of KS for bacteria ranged from 4 to $>20 \mathrm{mg} / \mathrm{ml}$. S. aureus was shown to be very resistant, and an accurate MIC value was not obtained for the studied KS concentrations. For the other bacteria, different sensitivities to KS action were observed. Stanojević et al. (2010) also studied the inhibitory effect of KS on various bacteria. In their work, E. coli and Erwinia carotovora (syn.

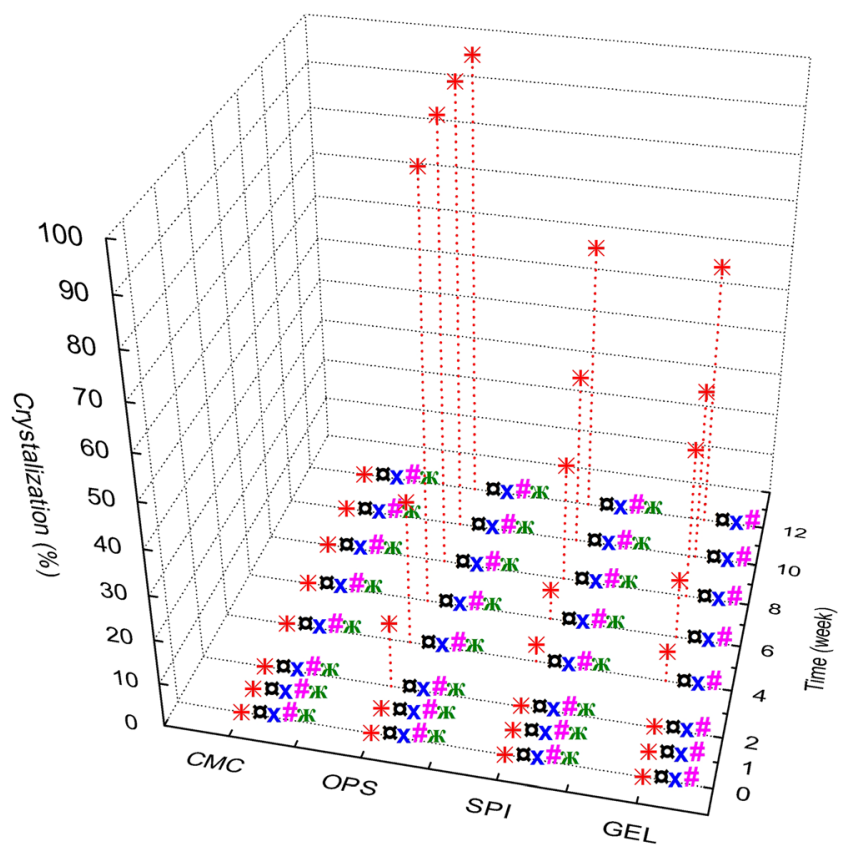

* $0 \% \mathrm{KS} \quad 1.0 \% \mathrm{KS} \quad \times 2.0 \% \mathrm{KS} \quad \# 3.0 \% \mathrm{KS} \quad$ ж $4.0 \% \mathrm{KS}$

Fig. 2 Degree of sorbitol crystallization found in biopolimer-candelilla wax emulsion films during storage at $25^{\circ} \mathrm{C}$ and $50 \% \mathrm{RH}$
P. carotovorum) were more sensitive to $\mathrm{KS}$ (MIC $=5 \mathrm{mg} / \mathrm{ml}$ ) than Bacillus spp., S. aureus, as well as other bacteria (MIC = $10 \mathrm{mg} / \mathrm{ml}$ ). The results of our study seem to be partially consistent with these findings. In a study described by Pérez et al. (2014), the MICs of KS for pathogenic strains of $E$. coli at $\mathrm{pH} 6.0$ were $2.5-5.0 \mathrm{mg} / \mathrm{ml}$. These authors showed that the activity of KS was strongly dependent on $\mathrm{pH}$; the KS concentrations needed to inhibit microbial growth in a liquid medium at $\mathrm{pH} 6.0$ was 2-4 levels higher than at $\mathrm{pH}$ 5.2. In the present paper, the $\mathrm{pH}$ value of the medium was optimal for growth of bacteria ( $\mathrm{pH} 7.0$ ), which most evidently reduced the antimicrobial efficiency of KS (MIC value for E. coli was $10 \mathrm{mg} / \mathrm{ml})$.

Among the tested fungi, $B$. cinerea and M. fructigena were the most susceptible to $\mathrm{KS}$ (MFC $=0.2 \mathrm{mg} / \mathrm{ml}$ ). A. alternata did not grow in liquid medium containing $\mathrm{KS}$ at concentrations of $3 \mathrm{mg} / \mathrm{ml}$ (and higher), and its MFC was only slightly higher than MIC. $R$. nigricans was the most KS-resistant fungus. In spite of no sign of mycelial growth at KS concentration $8 \mathrm{mg} / \mathrm{ml}, 18 \mathrm{mg} / \mathrm{ml}$ was needed for inhibition of colony formation by R. nigricans (Table 3).

\section{Antimicrobial Activity of Films}

The antimicrobial activity of different biopolymeric emulsion films incorporated with KS against the bacteria and filamentous fungi is shown in Tables 4 and 5. The control films did not show any inhibitory effect on any of the tested microorganisms. In turn, all KS-containing films revealed an antimicrobial effect, which demonstrates that, regardless of the filmforming agent, sorbate remained chemically active in the films. As expected, the inhibition zone diameter of all tested microorganisms increased by the increase of KS content in the films. Different susceptibilities of the indicator microorganisms to KS incorporated into the films were observed. Among bacteria, $S$. aureus was the most resistant to KS. In turn, the inhibitory zones were markedly high for $B$. cereus and $E$. coli (Table 4). Similar results were observed in the study by Shen et al. (2010), where sweet potato starch films incorporated with KS $(5-15 \% w / w)$ were not effective on $S$. aureus, while films containing $15 \% \mathrm{KS}$ efficiently inhibited growth of E. coli. In turn, Pranoto et al. (2005) demonstrated the KSincorporated chitosan films (50-200 $\mathrm{mg} / \mathrm{g}$ of chitosan) were effective against $S$. aureus, Listeria monocytogenes, and $B$. cereus, but not against E. coli and Salmonella typhimirium. Interestingly, increasing KS levels higher than $100 \mathrm{mg} / \mathrm{g}$ of chitosan did not significantly improve the antimicrobial effect, which according to the authors was due to chemical interaction between amino groups of chitosan and carboxyl groups of $\mathrm{KS}$, diminishing the release of KS into medium surrounding the film discs. The interactions between biopolymeric carriers and KS most likely also occurred in the present study, which 
Table 3 The minimal inhibitory concentration (MIC), minimal bactericidal concentration (MBC), and minimal fungicidal concentration (MFC) values of potassium sorbate

\begin{tabular}{|c|c|c|c|c|c|}
\hline \multirow[t]{2}{*}{ Bacteria } & \multicolumn{2}{|c|}{$\mathrm{KS}(\mathrm{mg} / \mathrm{ml})$} & \multirow[t]{2}{*}{ Fungi } & \multicolumn{2}{|c|}{$\mathrm{KS}(\mathrm{mg} / \mathrm{ml})$} \\
\hline & MIC & $\mathrm{MBC}$ & & MIC & MFC \\
\hline E. coli & 10.0 & 12.0 & B. cinerea & $<0.2$ & 0.2 \\
\hline P. carotovorum & 4.0 & 7.0 & M. fructigena & $<0.2$ & 0.2 \\
\hline S. aureus & $>20.0$ & $>20.0$ & A. alternata & 3.0 & 4.0 \\
\hline B. cereus & 10.0 & 16.0 & R. nigricans & 8.0 & 18.0 \\
\hline
\end{tabular}

was indirectly evidenced by changes in some functional properties of the films (Tables 1 and 2). Shen et al. (2010) speculated that the hydrogen bonding reactions between the carbox$\mathrm{yl}$ group of $\mathrm{KS}$ and the - $\mathrm{OH}$ groups of starch were responsible for the inefficient action of potato starch films containing $\mathrm{KS}$ at low levels. Ozdemir and Floros (2003) observed the decrease in KS diffusivity with increases in the amount of protein and beeswax in the whey protein films, which also indicates the great importance of interactions between KS and carriers for the antimicrobial action. From the results of our study, it can be seen that the inhibitory effect of KS tended to be lowest in SPI emulsion films, especially when low concentrations of the preservative were used (Tables 3 and 4). This result may be explained by the fact that soy proteins contain a wide range of functional groups that most likely were able to interact with $\mathrm{KS}$. Chemical bonding of KS by the polymers can explain in part the significant differences between MIC or
$\mathrm{MBC} / \mathrm{MFC}$ values and the relatively high concentrations of $\mathrm{KS}$ needed for the inhibition of microbial growth in the disc diffusion method. The tests in liquid medium only consider the $\mathrm{pH}$ of the media and active agent concentration. However, when a preservative is included in a complex matrix, such as an edible film over a solid media (e.g., agar or food), both the $\mathrm{pH}$ as well as interactions with the carrier and food model system must be considered in order to induce or improve the antimicrobial activity (Pérez et al. 2014). Sorbates are effective at $\mathrm{pH}$ up to 6.5 , but become more effective as the $\mathrm{pH}$ decreases (Stopforth et al. 2005). The $\mathrm{pH}$ measurements conducted in our study revealed that despite the considerable differences between acidity of control FFSs, the differences between $\mathrm{pH}$ values of KS-incorporated FFSs were not so big (Table 1). Hence, it can be concluded that the antimicrobial effectiveness of the films was not associated with their $\mathrm{pH}$.
Table 4 Antibacterial activity of biopolimer-candelilla wax emulsion films containing potassium sorbate

Values with the same superscript letters within a column are not significantly different $(p<0.05)$

n.a. not analyzed (films adhered to the casting surface)

\begin{tabular}{|c|c|c|c|c|c|}
\hline \multirow[t]{2}{*}{ Films } & \multirow[t]{2}{*}{ KS (\%) } & \multicolumn{4}{|c|}{ Inhibition zone diameter (mm) } \\
\hline & & S. aureus & B. cereus & E. coli & P.carotovorum \\
\hline \multirow[t]{5}{*}{$\mathrm{CMC}$} & 0 & $0.00 \pm 0.00^{\mathrm{a}}$ & $0.00 \pm 0.00^{\mathrm{a}}$ & $0.00 \pm 0.00^{\mathrm{a}}$ & $0.00 \pm 0.00^{\mathrm{a}}$ \\
\hline & 1.0 & $0.00 \pm 0.00^{\mathrm{a}}$ & $10.66 \pm 1.15^{\mathrm{c}}$ & $9.00 \pm 1.00^{\mathrm{c}}$ & $4.33 \pm 0.58^{\mathrm{b}}$ \\
\hline & 2.0 & $0.00 \pm 0.00^{\mathrm{a}}$ & $12.33 \pm 0.58^{\mathrm{d}}$ & $13.50 \pm 0.50^{\mathrm{f}}$ & $10.33 \pm 0.58^{\mathrm{e}}$ \\
\hline & 3.0 & $0.00 \pm 0.00^{\mathrm{a}}$ & $15.33 \pm 0.58^{\mathrm{ef}}$ & $15.67 \pm 0.58^{\mathrm{g}}$ & $14.67 \pm 0.58^{\mathrm{g}}$ \\
\hline & 4.0 & $1.00 \pm 0.00^{\mathrm{b}}$ & $23.00 \pm 1.00^{\mathrm{i}}$ & $17.33 \pm 0.58^{\mathrm{h}}$ & $18.00 \pm 0.00^{\mathrm{hi}}$ \\
\hline \multirow[t]{5}{*}{ OPS } & 0 & $0.00 \pm 0.00^{\mathrm{a}}$ & $0.00 \pm 0.00^{\mathrm{a}}$ & $0.00 \pm 0.00^{\mathrm{a}}$ & $0.00 \pm 0.00^{\mathrm{a}}$ \\
\hline & 1.0 & $0.00 \pm 0.00^{\mathrm{a}}$ & $11.30 \pm 0.58^{\mathrm{cd}}$ & $11.3 \pm 0.58^{\mathrm{de}}$ & $7.33 \pm 0.58^{\mathrm{c}}$ \\
\hline & 2.0 & $0.33 \pm 0.58^{\mathrm{ab}}$ & $12.30 \pm 0.58^{\mathrm{d}}$ & $13.00 \pm 1.00^{\mathrm{f}}$ & $9.33 \pm 0.58^{\mathrm{d}}$ \\
\hline & 3.0 & $4.67 \pm 1.15^{\mathrm{d}}$ & $14.67 \pm 0.58^{\mathrm{e}}$ & $15.83 \pm 0.76^{\mathrm{g}}$ & $12.33 \pm 0.58^{\mathrm{f}}$ \\
\hline & 4.0 & $5.00 \pm 1.00^{\mathrm{d}}$ & $17.33 \pm 0.58^{\mathrm{g}}$ & $18.17 \pm 0.29^{\mathrm{h}}$ & $15.33 \pm 0.58^{\mathrm{g}}$ \\
\hline \multirow[t]{5}{*}{ SPI } & 0 & $0.00 \pm 0.00^{\mathrm{a}}$ & $0.00 \pm 0.00^{\mathrm{a}}$ & $0.00 \pm 0.00^{\mathrm{a}}$ & $0.00 \pm 0.00^{\mathrm{a}}$ \\
\hline & 1.0 & $0.00 \pm 0.00^{\mathrm{a}}$ & $8.33 \pm 0.58^{b}$ & $9.67 \pm 0.58^{\mathrm{c}}$ & $4.33 \pm 0.58^{\mathrm{b}}$ \\
\hline & 2.0 & $1.00 \pm 1.00^{\mathrm{b}}$ & $10.33 \pm 0.58^{\mathrm{c}}$ & $10.67 \pm 0.58^{\mathrm{d}}$ & $8.67 \pm 1.15^{\mathrm{d}}$ \\
\hline & 3.0 & $2.50 \pm 0.50^{\mathrm{c}}$ & $14.33 \pm 0.58^{\mathrm{e}}$ & $11.83 \pm 0.29^{\mathrm{e}}$ & $10.67 \pm 0.58^{\mathrm{e}}$ \\
\hline & 4.0 & $4.33 \pm 0.58^{\mathrm{d}}$ & $16.17 \pm 0.29^{\mathrm{f}}$ & $13.33 \pm 1.15^{\mathrm{f}}$ & $18.67 \pm 1.15^{\mathrm{i}}$ \\
\hline \multirow[t]{5}{*}{ GEL } & 0 & $0.00 \pm 0.00^{\mathrm{a}}$ & $0.00 \pm 0.00^{\mathrm{a}}$ & $0.00 \pm 0.00^{\mathrm{a}}$ & $0.00 \pm 0.00^{\mathrm{a}}$ \\
\hline & 1.0 & $0.00 \pm 0.00^{\mathrm{a}}$ & $11.00 \pm 0.00^{\mathrm{c}}$ & $7.50 \pm 0.50^{\mathrm{b}}$ & $11.67 \pm 0.58^{\mathrm{f}}$ \\
\hline & 2.0 & $0.00 \pm 0.00^{\mathrm{a}}$ & $14.33 \pm 1.15^{\mathrm{e}}$ & $7.67 \pm 0.58^{\mathrm{b}}$ & $15.33 \pm 0.58^{\mathrm{g}}$ \\
\hline & 3.0 & $2.00 \pm 0.00^{\mathrm{c}}$ & $19.00 \pm 1.00^{\mathrm{h}}$ & $11.33 \pm 0.58^{\mathrm{de}}$ & $17.67 \pm 0.58^{\mathrm{h}}$ \\
\hline & 4.0 & n.a. & n.a. & n.a. & n.a. \\
\hline
\end{tabular}


Table 5 Antifungal activity of biopolimer-candelilla wax emulsion films containing potassium sorbate
Values with the same superscript letters within a column are not significantly different $(p<0.05)$

n.a. not analyzed (films adhered to the casting surface)

\begin{tabular}{|c|c|c|c|c|c|}
\hline \multirow[t]{2}{*}{ Films } & \multirow[t]{2}{*}{ KS (\%) } & \multicolumn{4}{|c|}{ Inhibition zone diameter (mm) } \\
\hline & & R. nigricans & A. alternata & B. cinerea & M. fructigena \\
\hline \multirow[t]{5}{*}{$\mathrm{CMC}$} & 0 & $0.00 \pm 0.00^{\mathrm{a}}$ & $0.00 \pm 0.00^{\mathrm{a}}$ & $0.00 \pm 0.00^{\mathrm{a}}$ & $0.00 \pm 0.00^{\mathrm{a}}$ \\
\hline & 1.0 & $3.00 \pm 0.00^{\mathrm{b}}$ & $0.00 \pm 0.00^{\mathrm{a}}$ & $1.50 \pm 0.50^{\mathrm{b}}$ & $15.66 \pm 0.58^{\mathrm{c}}$ \\
\hline & 2.0 & $6.00 \pm 0.00^{\mathrm{c}}$ & $10.00 \pm 1.00^{\mathrm{de}}$ & $12.67 \pm 1.15^{\mathrm{f}}$ & $17.00 \pm 1.00^{\mathrm{d}}$ \\
\hline & 3.0 & $8.33 \pm 0.58^{\mathrm{d}}$ & $10.67 \pm 1.15^{\mathrm{ef}}$ & $18.67 \pm 1.15^{\mathrm{hi}}$ & $20.00 \pm 0.00^{\mathrm{g}}$ \\
\hline & 4.0 & $12.67 \pm 0.58^{\mathrm{e}}$ & $19.00 \pm 1.00^{\mathrm{g}}$ & $20.00 \pm 0.00^{\mathrm{i}}$ & $24.33 \pm 1.53^{\mathrm{h}}$ \\
\hline \multirow[t]{5}{*}{ OPS } & 0 & $0.00 \pm 0.00^{\mathrm{a}}$ & $0.00 \pm 0.00^{\mathrm{a}}$ & $0.00 \pm 0.00^{\mathrm{a}}$ & $0.00 \pm 0.00^{\mathrm{a}}$ \\
\hline & 1.0 & $0.00 \pm 0.00^{\mathrm{a}}$ & $0.00 \pm 0.00^{\mathrm{a}}$ & $7.67 \pm 1.53^{\mathrm{d}}$ & $15.67 \pm 0.58^{\mathrm{c}}$ \\
\hline & 2.0 & $6.00 \pm 0.00^{\mathrm{c}}$ & $4.67 \pm 1.15^{\mathrm{c}}$ & $13.33 \pm 1.15^{\mathrm{f}}$ & $17.33 \pm 1.15^{\mathrm{d}}$ \\
\hline & 3.0 & $8.33 \pm 0.58^{\mathrm{d}}$ & $8.67 \pm 1.15^{\mathrm{d}}$ & $15.33 \pm 1.15^{\mathrm{g}}$ & $18.67 \pm 1.15^{\mathrm{ef}}$ \\
\hline & 4.0 & $14.00 \pm 2.00^{\mathrm{f}}$ & $21.67 \pm 1.53^{\mathrm{h}}$ & $17.33 \pm 2.31^{\mathrm{h}}$ & $27.00 \pm 1.00^{\mathrm{j}}$ \\
\hline \multirow[t]{5}{*}{ SPI } & 0 & $0.00 \pm 0.00^{\mathrm{a}}$ & $0.00 \pm 0.00^{\mathrm{a}}$ & $0.00 \pm 0.00^{\mathrm{a}}$ & $0.00 \pm 0.00^{\mathrm{a}}$ \\
\hline & 1.0 & $0.00 \pm 0.00^{\mathrm{a}}$ & $0.00 \pm 0.00^{\mathrm{a}}$ & $0.00 \pm 0.00^{\mathrm{a}}$ & $11.67 \pm 1.53^{\mathrm{b}}$ \\
\hline & 2.0 & $3.00 \pm 1.00^{\mathrm{b}}$ & $9.33 \pm 0.58^{\mathrm{de}}$ & $9.67 \pm 0.58^{\mathrm{e}}$ & $15.33 \pm 0.58^{\mathrm{c}}$ \\
\hline & 3.0 & $7.67 \pm 0.58^{\mathrm{d}}$ & $8.67 \pm 0.58^{\mathrm{d}}$ & $18.67 \pm 1.15^{\mathrm{hi}}$ & $19.00 \pm 1.00^{\mathrm{fg}}$ \\
\hline & 4.0 & $15.33 \pm 0.58^{\mathrm{g}}$ & $24.67 \pm 1.15^{\mathrm{i}}$ & $21.67 \pm 0.58^{\mathrm{j}}$ & $25.67 \pm 0.58^{\mathrm{i}}$ \\
\hline \multirow[t]{5}{*}{ GEL } & 0 & $0.00 \pm 0.00^{\mathrm{a}}$ & $0.00 \pm 0.00^{\mathrm{a}}$ & $0.00 \pm 0.00^{\mathrm{a}}$ & $0.00 \pm 0.00^{\mathrm{a}}$ \\
\hline & 1.0 & $0.00 \pm 0.00^{\mathrm{a}}$ & $1.50 \pm 0.50^{\mathrm{b}}$ & $3.33 \pm 0.58^{\mathrm{c}}$ & $17.67 \pm 0.58^{\mathrm{de}}$ \\
\hline & 2.0 & $5.67 \pm 0.58^{\mathrm{c}}$ & $5.00 \pm 1.00^{\mathrm{c}}$ & $12.33 \pm 0.58^{\mathrm{f}}$ & $20.00 \pm 0.00^{\mathrm{g}}$ \\
\hline & 3.0 & $12.67 \pm 1.15^{\mathrm{e}}$ & $12.00 \pm 2.00^{\mathrm{f}}$ & $17.67 \pm 0.58^{\mathrm{h}}$ & $25.67 \pm 0.58^{\mathrm{i}}$ \\
\hline & 4.0 & n.a. & n.a. & n.a. & n.a. \\
\hline
\end{tabular}

As can be seen from Table 5, M. fructigena was very sensitive to KS-incorporated films; at $4.0 \%$ of $\mathrm{KS}$, inhibition zone diameters were $24.33-27.00 \mathrm{~mm}$, depending on the biopolymer type. In turn, $R$. nigricans was able to adapt to the presence of $\mathrm{KS}$; its inhibitory zones reduced themselves during the incubation period. Sayanjali et al. (2011) used the agar diffusion method to study the fungicidal effect of CMC films incorporated with KS $(1-4 \% w / v)$ on some Aspergillus species. They reported that maximum inhibition zones $(\sim 6.0 \mathrm{~mm})$ were observed for 3 and $4 \%$ of $\mathrm{KS}$. The lower concentrations of KS in CMC films were much less effective, giving inhibition zones at the level of $0-2 \mathrm{~mm}$, depending on the strain. A similar effect was observed in our study. The increase in $\mathrm{KS}$ concentration from 1 to $4 \%$ in many cases resulted in a several times higher inhibition of mycelium growth. Türe et al. (2012) showed that wheat gluten films containing KS effectively inhibited the growth of Aspergillus niger when the concentration of preservative was $10 \% \mathrm{w} / \mathrm{w}$ (inhibition zone was about $3 \mathrm{~mm}$ ), whereas $2.5 \%$ of KS was enough for the inhibition of Fusarium incarnatum (inhibition zone $=3.7 \mathrm{~mm}$ ). This result revealed that $\mathrm{KS}$-containing films were more effective against slow-growing mold (Fusarium) than fast-growing mold (Aspergillus). Our observations followed a similar trend. The fast-growing Rhizopus was the most KS-resistant fungus. On the other hand, A. alternata, $B$. cinerea, and $M$. fructigena, which grew relatively slowly, were more susceptible to $\mathrm{KS}$ diffusing from the film discs to the medium.

\section{Conclusion}

This paper is a contribution to basic and applied knowledge related to the development of KS-incorporated edible films made from various biopolymers. The CMC, OPS, SPI, and GEL emulsion-based films can act as carriers for KS; however, relatively high $\mathrm{KS}$ addition levels, $0.2-0.4 \mathrm{~g}$ per $1 \mathrm{~g}$ of filmforming agent, were needed to induce antimicrobial action, observed in the disc diffusion test. A rise in the KS concentration resulted in films with higher antimicrobial activity. The type of polymer matrix used affected KS diffusivity. In general, KS was the least effective in SPI films, probably due to trapping of the preservative by the protein functional groups. $\mathrm{KS}$ modified the physicochemical properties of the films, and the practical limit of its addition was $0.6 \mathrm{~g} \mathrm{KS}$ per gram of GEL; and $0.8 \mathrm{~g} \mathrm{KS}$ per gram of CMC, OPS, and SPI. As the KS content increased, the OPS, SPI, and GEL became more hygroscopic and adhesive, which could be a drawback in many packaging applications. Since KS presented strong plasticizing effect, the formation of active films without Sor addition should be considered in future research for 
optimizing film properties. Considering the possibility of applying the antimicrobial films to the food process, CMC emulsion-based films can be recommended for use as packaging material. These films are not sticky, are rapidly and completely water-soluble, and exhibit relatively good mechanical resistance. We suggest their use as easily washable coatings for the treatment of food surfaces, the typical point of entry for pathogens and a likely location of maximum microbial contamination. Further studies should follow to determine the ability of these selected materials to control microorganisms growth in in vivo tests, e.g., with fresh fruits or vegetables, and to assess their performance in food products in relation to product quality and consumer acceptance.

Acknowledgements This work was financially supported by the National Science Centre (Poland) under Grant No. N N312 501540.

Open Access This article is distributed under the terms of the Creative Commons Attribution License which permits any use, distribution, and reproduction in any medium, provided the original author(s) and the source are credited.

\section{References}

Aitken, A., \& Learmonth, M. P. (2000). Protein determination by UV absorption. In J. M. Walker (Ed.), The protein protocols handbook (pp. 3-6). Totowa: Human Press.

Al-Hassan, A. A., \& Norziah, M. H. (2012). Starch-gelatin edible films: water vapor permeability and mechanical properties as affected by plasticizers. Food Hydrocolloids, 26(1), 108-117.

Allsopp, D., Seal, K. J., \& Gaylarde, C. C. (2004). Introduction to biodeterioration. Cambridge: Cambridge University Press.

Basch, C., Jagus, R., \& Flores, S. (2013). Physical and antimicrobial properties of tapioca starch-HPMC edible films incorporated with nisin and/or potassium sorbate. Food and Bioprocess Technology, 6(9), 2419-2428.

Bergo, P., Moraes, I. C. F., \& Sobral, P. J. A. (2013). Effects of plasticizer concentration and type on moisture content in gelatin films. Food Hydrocolloids, 32(2), 412-415.

Commission Directive 2007/68/EC of 27 November (2007) amending Annex IIIa to Directive 2000/13/EC of the European Parliament and of the Council as regards certain food ingredients. Official Journal of the European Union, L 310/11.

Famá, L., Rojas, A. M., Goyanes, S., \& Gerschenson, L. (2005). Mechanical properties of tapioca-starch edible films containing sorbates. LWT - Food Science and Technology, 38(6), 631-639.

Farahnaky, A., Saberi, B., \& Majzoobi, M. (2013). Effect of glycerol on physical and mechanical properties of wheat starch edible films. Journal of Texture Studies, 44(3), 176-186.

Flores, S., Famá, L., Rojas, A. M., Goyanes, S., \& Gerschenson, L. (2007). Physical properties of tapioca-starch edible films: Influence of filmmaking and potassium sorbate. Food Research International, 40(2), 257-265.

Franssen, L. R., Rumsey, T. R., \& Krochta, J. M. (2004). Whey protein film composition effects on potassium sorbate and natamycin diffusion. Journal of Food Science, 69(5), C347-C350.

Garcia, L. C., Pereira, L. M., de Luca Sarantópoulos, C. I. G., \& Hubinger, M. D. (2012). Effect of antimicrobial starch edible coating on shelf-life of fresh strawberries. Packaging Technology and Science, 25(7), 413-425.
Ghorpade, V. M., Li, H., Gennadios, A., \& Hanna, M. A. (1995). Chemically modified soy protein films. Transactions of the Asae, 38(6), 1805-1808.

Glicksman, M. (1963). Utilization of synthetic gums in the food industry. In C. O. Chichester, M. E. Marcel, \& S. G. Franklin (Eds.), Advances in food research (Vol. 12, pp. 283-366). New York: Academic.

Han, J. H., \& Floros, J. D. (1997). Casting antimicrobial packaging films and measuring their physical properties and antimicrobial activity. Journal of Plastic Film \& Sheeting, 13(4), 287-298.

Kołodziejska, I., \& Piotrowska, B. (2007). The water vapour permeability, mechanical properties and solubility of fish gelatin-chitosan films modified with transglutaminase or 1-ethyl-3-(3dimethylaminopropyl) carbodiimide (EDC) and plasticized with glycerol. Food Chemistry, 103(2), 295-300.

Kowalczyk, D., \& Baraniak, B. (2011). Effects of plasticizers, pH and heating of film-forming solution on the properties of pea protein isolate films. Journal of Food Engineering, 105(2), 295-305.

Kowalczyk, D., \& Baraniak, B. (2014). Effect of candelilla wax on functional properties of biopolymer emulsion films - a comparative study. Food Hydrocolloids, 41, 195-209.

Kowalczyk, D., Gustaw, W., Świeca, M., \& Baraniak, B. (2014). A study on the mechanical properties of pea protein isolate films. Journal of Food Processing and Preservation, 38(4), 1726-1736.

Kristo, E., Koutsoumanis, K. P., \& Biliaderis, C. G. (2008). Thermal, mechanical and water vapor barrier properties of sodium caseinate films containing antimicrobials and their inhibitory action on Listeria monocytogenes. Food Hydrocolloids, 22(3), 373-386.

Krochta, J. M. (2002). Proteins as raw materials for films and coatings: definitions, current status, and opportunities. In A. Gennadios (Ed.), Protein-based films and coatings (pp. 1-41). Boca Raton, FL: CRC Press.

Kuakpetoon, D., \& Wang, Y. (2001). Characterization of different starches oxidized by hypochlorite. Starch-Starke, 53(5), 211-218.

Kurup, T. R. R., Wan, L. S. C., \& Chan, L. W. (1995). Interaction of preservatives with macromolecules. Part II. Cellulose derivatives. Pharmaceutica Acta Helvetiae, 70(2), 187-193.

Mansour, Z., \& Guth, E. P. (1968). Complexing behavior of starches with certain pharmaceuticals. Journal of Pharmaceutical Sciences, 57(3), 404-411.

Mehyar, G. F., Al-Qadiri, H. M., \& Swanson, B. G. (2014). Edible coatings and retention of potassium sorbate on apples, tomatoes and cucumbers to improve antifungal activity during refrigerated storage. Journal of Food Processing and Preservation, 38(1), 175182.

Ofman, M. H., Campos, C. A., \& Gerschenson, L. N. (2004). Effect of preservatives on the functional properties of tapioca starch: analysis of interactions. LWT - Food Science and Technology, 37(3), 355361.

Ozdemir, M., \& Floros, J. D. (2001). Analysis and modeling of potassium sorbate diffusion through edible whey protein films. Journal of Food Engineering, 47(2), 149-155.

Ozdemir, M., \& Floros, J. D. (2003). Film composition effects on diffusion of potassium sorbate through whey protein films. Journal of Food Science, 68(2), 511-516.

Pérez, L. M., Soazo, M. V., Balagué, C. E., Rubiolo, A. C., \& Verdini, R. A. (2014). Effect of pH on the effectiveness of whey protein/ glycerol edible films containing potassium sorbate to control nonO157 shiga toxin-producing Escherichia coli in ready-to-eat foods. Food Control, 37, 298-304.

PN-ISO 2528 (2000). Sheet materials - Determination of water vapour transmission rate - Gravimetric (dish) method.

Pranoto, Y., Rakshit, S. K., \& Salokhe, V. M. (2005). Enhancing antimicrobial activity of chitosan films by incorporating garlic oil, potassium sorbate and nisin. LWT - Food Science and Technology, 38(8), 859-865. 
Sayanjali, S., Ghanbarzadeh, B., \& Ghiassifar, S. (2011). Evaluation of antimicrobial and physical properties of edible film based on carboxymethyl cellulose containing potassium sorbate on some mycotoxigenic Aspergillus species in fresh pistachios. LWT - Food Science and Technology, 44(4), 1133-1138.

Shen, X. L., Wu, J. M., Chen, Y., \& Zhao, G. (2010). Antimicrobial and physical properties of sweet potato starch films incorporated with potassium sorbate or chitosan. Food Hydrocolloids, 24(4), 285-290.

Stanojević, D., Čomić, L., Stefanović, O., \& Solujić-Sukdolak, S. (2010). In vitro synergistic antibacterial activity of Salvia officinalis L. and some preservatives. Archives of Biological Sciences, 62(1), 175183.

Stopforth, J. D., Sofos, J. N., \& Busta, F. F. (2005). Sorbic acid and sorbates. In P. M. Davidson, J. N. Sofos, \& A. L. Branen (Eds.), Antimicrobials in food (3rd ed., pp. 49-90). Boca Raton: CRC Press.
Theron, M. M., \& Rykers, J. F. (2011). Organic acids and food preservation. Boca Raton: CRC Press (Chapter 2).

Türe, H., Gällstedt, M., \& Hedenqvist, M. S. (2012). Antimicrobial compression-moulded wheat gluten films containing potassium sorbate. Food Research International, 45(1), 109-115.

Valencia-Chamorro, S. A., Palou, L., del Río, M. A., \& Pérez-Gago, M. B. (2008). Inhibition of Penicillium digitatum and Penicillium italicum by hydroxypropyl methylcellulose-lipid edible composite films containing food additives with antifungal properties. Journal of Agricultural and Food Chemistry, 56(23), 11270-11278.

Wypych, G. (2004). Handbook of plasticizers. Toronto: ChemTec Publishing (Chapter 1).

Yang, L., \& Paulson, A. T. (2000). Mechanical and water vapour barrier properties of edible gellan films. Food Research International, $33(7), 563-570$. 